\title{
EchoGéo
}

21 | 2012

Pays émergents

\section{For a social geography of emerging countries}

Introduction to the themed issue

Antoine Fleury et Myriam Houssay-Holzschuch

\section{(2) OpenEdition}

Journals

Édition électronique

URL : https://journals.openedition.org/echogeo/13287

DOI : $10.4000 /$ echogeo. 13287

ISSN : 1963-1197

Éditeur

Pôle de recherche pour l'organisation et la diffusion de l'information géographique (CNRS UMR 8586)

Référence électronique

Antoine Fleury et Myriam Houssay-Holzschuch, "For a social geography of emerging countries », EchoGéo [En ligne], 21 | 2012, mis en ligne le 16 janvier 2013, consulté le 10 août 2021. URL : http:// journals.openedition.org/echogeo/13287 ; DOI : https://doi.org/10.4000/echogeo.13287

Ce document a été généré automatiquement le 10 août 2021.

EchoGéo est mis à disposition selon les termes de la licence Creative Commons Attribution - Pas d'Utilisation Commerciale - Pas de Modification 4.0 International (CC BY-NC-ND) 


\title{
For a social geography of emerging countries
}

\author{
Introduction to the themed issue
}

Antoine Fleury et Myriam Houssay-Holzschuch

1 New economic world order, new geographies of development, new powers... A whole range of expressions has appeared in the past three decades to coin the major and multi-dimensional changes that have affected global political economics. More specifically, those expressions refer to a transition towards a multi-polar world: the domination of the West and later the Triade is now counterbalanced by the economic and perhaps political power of countries that were once called under-developed - China being the archetype. Those countries are now included under the umbrella term of "emerging countries", a reference to their relatively recent arrival into the concert of great powers. More broadly, the trope of emergence is frequently called upon to designate the vast, shifting complex of political, economic, social and cultural phenomena that have brought about a reconfiguration so dramatic that the term of "emerging worlds" - note the use of the plural - is now used (Atlas du Monde

diplomatique, 2012). Emergence has become a new category, understood as a way of ordering the world in order to better describe or conceptualize it.

2 However, this label is caught between its ubiquity - which cannot be very productive scientifically - and its heavy focus on economic and political phenomena. This special issue $^{1}$ aims to go beyond this opposition: starting from empirical observation we will show how reconfigurations brought about by "emergence" have important repercussions in the social field amongst others. We will adopt a critical approach in order to reconstruct power relations as well as practices. The aim is to understand how, in what should really be called the majority world, the different actors' everyday geographies are constantly shifting. 


\section{Categorisation as an issue}

3 First of all, it needs to be emphasized that the term "emergence" belongs to a history of categories that were invented to think the world, its diversity, its disparities and inequalities. We all know that saying is doing, and naming is claiming ownership: the social construction of categories, spatial or other, is a common scientific practice, which needs to be subjected to a critical analysis. A tool for this analysis could be Schaffter, Fall and Debarbieux (2010)'s triad of terms: commodification - naturalization - fetichization.

4 After World War Two, in a teleological, normative and economics-centred perspective, people used the terms "developing countries" and later "Third World" - the latter referred to a posture of self-affirmation and political activism at the time of the Cold War - before the term of "South" appeared, singular, then plural in some languages: a term that seems to be less charged politically because of its naturalisation (GervaisLambony and Landy, 2007). "The erosion of analytical frameworks and political models, as well as the great diversity of economic realities, created awareness of the multiplicity of national trajectories." (Gabas and Losch, 2008, p. 27). This led to the appearance of new terms that aimed to account for this diversity: newly industrialized countries (NIC), less advanced countries ${ }^{2}$ (LAC), transition countries (countries from the former Soviet bloc), etc. The term of "emerging country", now widely used, participated in this evolution, even though it does not refer to a unified group of countries in international statistics or to a set of quantified criteria. It first appeared in the world of finance in the 1980s (Bret, 2011; Gabas and Losch, 2008). People then started to use the words emerging markets to refer to countries having undergone a quick growth and offering investment opportunities for businesses from richer countries. The term eventually became widespread across the media and academic world.

5 Three major phenomena, each connected to in-depth economical transformations in several groups of countries, have helped consolidate the category of "emerging country". First of all, changes in the geography of industrial production, with "developing" countries gradually gaining more importance: the "Asian dragons" (Hong-Kong, Taiwan, North Korea and Singapore"), followed by the "baby dragons" (Malaysia, Thailand, Indonesia and the Philippines) and even the South American "jaguars", caught the eye of bankers and investors, together with various economic and social mechanisms (development of tax-free zones, maquiladoras, business relocations...). A second dimension of the process is the introduction of economic reforms in a large portion of the former Soviet Bloc, as those countries engaged in a transition towards a market economy and went through a period of strong economic growth: China's opening-up policy through Special Economic Zones, Vietnam's Doi Moi, the dismantling of the USSR, and the economical and political "Europeanization" of central and western Europe countries. Finally, a number of "large" emerging countries (China, Brazil, Russia and India) made their entrance on the global economic and political stage. These countries are characterized by the large size of their populations and its corollary: a gigantic domestic market. China in particular played a major part in the process: its economic growth, its production and export capacity, its finance and credit power as well as the quick growth of its influence in the global geographies of 
power make the country a very unique force but also an archetype for emergence and the new global multipolarity.

However, the notion of emerging country or economy remains "remarkably unstable" (Sgard, 2008), with "fragile boundaries and floating definitions" (Gabas and Losch, 2008, p.26). We need to keep in mind the "disparity and volatility of the criteria used to define this category" (Piveteau and Rougier, 2010, p.3). International institutions use very different criteria from the academic or financial world, which accounts for huge variations in the number of countries that are classified under this category: the definition of "emerging countries" is therefore a shifting reality, with open boundaries both on the upper end - it includes countries which are now developed, such as South Korea - and lower end - with the inclusion of countries described as "on the way to emergence", like Maghreb countries. Two main approaches can be observed (Gabas and Losch, 2008, p.30). One offers a more restrictive approach, focussing on "large emerging countries" like China, Brazil, Russia and India, and defines emergence in opposition with the G7, sometimes including other countries like South Africa and Mexico. This approach has generated yet another classification, with the acronym BRIC proposed in 2001 by Jim O'Neill, an economist from Goldman Sachs. On the other hand, a more inclusive and classical approach gathers the countries that were once called "developing", to the exception of the least advanced ones. Alongside the core of countries described above, this approach includes a second circle of emerging countries with less economical and political power (like Chile and Turkey), and a third circle of vulnerable countries that have had hazardous and sometimes downwards trajectories (Argentina, Indonesia), as well as countries on the verge of emergence like Thailand, Vietnam, Malaysia, but also Egypt or the Maghreb ${ }^{3}$.

7 Those categories are highly controversial and diversely instrumentalized, both on the global and national scale. The category of BRIC itself remains fluid and is the object of serious power plays. In 2010, the BRIC countries, claiming O'Neill's terminology for themselves and forming a pressure group, offered South Africa, the main economic and political power on the African continent, to join them in order to form the BRICS. This extension of the perimeter of emergence was criticised by O'Neill, who highlighted South Africa's weaknesses and the dissymmetry between the four giants and this latecomer. The South African press turned the extension into a public debate around the boundaries of the term "emergence". So far, economic growth and development, reflected for instance by the HDI, had appeared as good indicators of emergence. However, South Africa, now a member of what increasingly appears as an official list of "truly emerging" countries, has seen its HDI decrease over the last ten years - mostly due to the disastrous effects of the AIDS pandemic (Houssay-Holzschuch, 2010). How can a country be called emerging if its level of human development is receding? Besides, high political and economical stakes in terms of image are attached to being "part of the club": in 2011 O'Neill himself suggested the term MIST, like some sort of second round of admissions, for Mexico, Indonesia, South Korea and Turkey.

8 The problematic nature of categorisation, whether scientific or political, will not of course stop it from being used - much to the contrary. "Emerging countries" in particular form an interesting object of study: not only because their very existence indicates global reconfigurations, but also because the fast changes those countries have undergone allow us to look into issues usually associated with "Northern countries" (industrial and financial geography, urban forms like gated communities or 
skyscrapers, public policies...) and others associated with "Southern countries" (a majority in poverty, to quote Michel Rochefort, the importance of the informal sector...) together with other more novel issues (social polarisation, new social movements...). Nevertheless, using this category must not lead us to essentialising it: this would be paradoxical for a notion that refers to deep, fast and multidimensional changes. We should also avoid compartimentalizing analyses (for instance by opposing emerging countries to "Northern" or "Southern" countries), to the detriment of an "ordinarist" approach such as Jenny Robinson's (2006). Beyond, we do hope that the category will contribute to building a de-centered geography (Robinson, 2003), where concepts are not developed simply from the Western core of knowledge production , but also in the majority world, which "emerging countries" are part of.

\section{Dominant approaches of emergence in social science: economics and geopolitics}

9 The notion of emergence as it has been applied to a number of countries since the 1980 s is deeply tainted by a disciplinary bias. In the social sciences, criteria proposed by economists prevail. According to C. Jaffrelot (2008), emerging countries are first and foremost defined by their "economic take-off", as demonstrated by some of those countries' growing importance in the global economy (China, India and Brazil in particular). China's GDP was for instance multiplied by 5.7 between 1980 and 2008, and that of India by 2.2. Emerging countries are also characterized by the fact that this take-off was closely connected to an "accelerated inclusion into global economy" (Jaffrelot, 2008): the words "globalisation growth" have been used for these countries (Sgard, 2008; Ruet, 2008). The growth of their exports - stimulated by under-evaluated currencies - and their ability to attract foreign capital since the 1990s (Bost, 2004) testify of the link between emergence and globalisation, just like the correlated "accelerated development of competitive and globalizing firms" (Piveteau and Rougier, 2010). Finally, various authors emphasize the relative institutional stability in so-called emerging countries. Emergence can therefore not be understood without being put into perspective over a longer period of time, in relation with "specific government configurations" (Gabas and Losch, 2008) and with relevant public policies (Piveteau and Rougier, 2010). Emergence is connected to insertion within global systems - which implies the adoption of new norms - and the active role of efficient states, able to consolidate economic growth by setting up operational market regulation bodies. Ultimately, the model of emerging countries might correspond to "a form of mixed economy", as those countries have been able to partly emancipate themselves from the liberal regulations of the Washington consensus ${ }^{5}$ "after those regulations had completed their core mission of bringing in private money and market rules, and in eroding corporatism" (Piveteau and Rougier, 2010, p.8). This model differs from three others: that of "countries that do not emerge at all", mostly in Africa, and whose failure could be connected to the failure of the State; that of "rentier economies", characterised by a hiatus between State-led financing and government on the one hand, and private and competitive economy on the other; finally, the model of countries "that took a liberal turn in the 1980's but without ever gaining the capacity to lead efficient public policies", like Venezuela, Argentina and even Russia ${ }^{6}$ (Sgard, 2008, pp. 52-53). 
10 Another perspective has become prominent in social sciences more recently: that of international relations and geopolitics. Many authors highlight the shift in powers associated to emergence: the status of emerging countries is consolidated, starting from their economic power, to the point where they become important players on the international scene (Milani, 2011). Jaffrelot (2008) even sees this eagerness to take part in global business one of the criteria of emergence, as does the economist Jean Coussy (2008) who proposes one additional criteria to define emerging countries: being in a position to pose a threat to the status of dominant countries. Emergence therefore points to a reversal in a world that is becoming truly multipolar, and to the end of Western hegemony. A number of those countries are first and foremost regional poles: they are part of regional networks and are implementing, like South Africa, an "emergence strategy" (Darbon, 2008, p.142) based on active diplomacy. Some of them came together in 2009 to form the BRICS (Brazil, Russia, India, China and South Africa), a political club aimed at joining up their actions, with a strong will to have a diplomatic influence on a world order which they feel they are excluded from. Finally, as was to be expected, emerging countries are starting to develop their military power to secure their independence and other countries' respect - in particular India and China (Giblin, 2011). China has an ambiguous status amongst the BRICS countries: it is perceived simultaneously by Western countries as an associate power, and by Southern countries as a respected leader; the country has all it takes to become the second hyper-power within the next ten years (Chambon, 2010). Emergence is visible in China's (and to a lesser extent India's) aggressive implantation on the African continent, in the country's diplomatic pressure on Northern countries (as exemplified by South Africa's lobbying to obtain a permanent seat as a representative of the African continent at the UN Security Council) or in growing investments into those countries through sovereign funds, and finally in strong tensions on the agricultural and energetic markets.

\section{Emergence as a multidimensional phenomenon: a social and cultural approach}

11 Within emerging countries, economic changes bring about considerable social and cultural changes. Although the controversial term of transition (demographic, urban, political, epidemiological...) has been used to describe them, we believe that those changes can first and foremost be understood and analysed as "compressed social change", because of their particularly fast and wide-reaching, and perhaps systemic, nature. Societies in emerging countries are affected by deep transformations, with a global improvement of the standard of living and education, and an intensification of movement - of people, goods, information, ideologies... in particular via new channels of communication (Appadurai, 1996; Inda and Rosaldo, 2002). Emergence can therefore be seen as a multidimensional phenomenon: it would be reductive to only account for it in terms of economy or international relations when the changes are of a social nature (Bret, 2011; Houssay-Holzschuch, 2007). Besides, such an analysis tends to favour macro approaches ${ }^{7}$, when the meso or even micro scale can provide a particularly good picture of change: studying those levels can allow us to uncover both the "local effects of emergence" but also the part played by other stakeholders (local authorities, individuals etc.) who might be the tenants of a "local will to emerge" (Morange, 2011, p. 348). Although "the notion of emergence is requiring time to enter geographers' 
toolboxes" (Morange, 2011, p.349), especially French ones, social and cultural geography does appear to have something to tell us about emergence. The major changes brought about by emergence mean that the social field is very dramatically restructured. The exponential development of an educated middle class - although this term remains vague - is one of the most striking facts of the last decade. This middle class tends to consume according to the same models as Northern countries, or aspire to those models. They send their children to University, travel and are open to the outside world (Bret, 2011). The car and the mall are the archetypes of those new modes of consumption (cf. Erkip, 2003, on Turkey), whose transmission is supported by the development of new channels of communication (Internet, TV...). In addition, the increasing importance of the middle classes is correlated by fast-growing social polarisation: the reconfiguration of the labour market has considerably accentuated disparities in terms of access to employment, income and working conditions. Although the emergence process does have the potential to create jobs, unemployment remains important in many emerging countries (Bret, 2011), as does the informal sector (Roy, 2011; Schneider et al., 2010; Simone, 2004 and 2010). Like Piveteau and Rougier remind us (2010), "the leading emerging countries are those with the highest Gini index, showing a strong concentration of wealth in the top decile". Latin America, and Brazil in particular, is the most affected, but inequalities have also grown in most Asian countries in the last ten years: in China, the Gini coefficient rose from 0,3 in the late 1970 s to 0,45 in 2002. According to the Chinese Commission for national development, the richest $10 \%$ of urban population own $45 \%$ of total wealth, against only $10 \%$ for the $10 \%$ poorest (Houssay-Holzschuch, 2007). As for the rise of consumer society, it contributes to social inequality by creating frustration, as manifested by the desire for a new way of life and access to leisure (Berry-Chikhaoui et al., 2007).

Social inequalities are echoed by growing territorial inequality. This again is connected to the very process of emergence, which often happens in a partial and fragmented way. Emergence produces inequalities on every geographical scale (Brett, 2011). In India as in Mexico, China or Brazil, strong national territorial inequalities are accentuated by the emergence process. China's case is a prime example: the coastal regions, which are responsible for a large portion of the $10 \%$ of annual growth, contrast with the inland regions, populated by 500 million farmers (Sanjuan, 2007). On a smaller scale, large cities are emblematic of those growing inequalities, reflected by the development of "Business improvement districts" in central areas (Peyroux et al., 2012), or the voluntary confinement of the rich in gated neighbourhoods (Capron, 2006). Emergence actually develops unevenly, depending on a favourable local context (development of a fabric of local businesses, growth of the middle class, presence of a creditworthy market, etc.) and on the concentration of foreign investment in areas that have been advertised more for a number of reasons (cost of investment, tax law, social and environmental regulations, better access to the global economy, etc.) (Bret, 2011). Ultimately, we are talking not so much about emerging countries as about emerging territories - interface areas, coasts, "free zones", cities or urban districts - or about "local emergence" (Morange, 2011), leaving behind a number of territories within each so-called emerging country. The spatial dimension of emergence is more akin to "a constellation of territories (...), connected together by information and communication networks", reminiscent of the "original historical configuration of Braudel's 'worldeconomy': a network of cities" (Gabas and Losch, 2008). 
13 Furthermore, economic disparities between countries with different trajectories have important consequences in a context of global reconfiguration. Globalisation generates a considerable growth in all types of exchanges and movement. In addition to the inequalities within the North and South - there is some South in the North and some North in the South - North-South movements are complemented by South-North flows (migratory flows, cultural influence, etc.) as well as huge South-South flows (migratory, economical, cultural, etc.). This has an impact on territoriality, and almost always creates economies of scale (Amin, 2002), together with the displacement and relocation of populations within different spatialities (Inda and Rosaldo, 2002): emerging countries are major platforms for those complex and interwoven processes. They export labour, both highly qualified and unqualified (Varrel, 2011), often through temporary circular migration, but also take in migrants from the surrounding area. They are affected by diasporas, both outwards (China, India, Turkey) and inwards (the presence of people of Indian origin in South Africa for instance). Unsurprisingly, those countries also occupy an in-between position as both receptors and producers in terms of culture. Bollywood is the archetypal example, together with South African cinema: the country screens US blockbusters, and sends Charlize Theron to Hollywood, together with films like Yesterday and Tsotsi, both nominated (and with the latter, winner) in the Oscar for best foreign language film. More importantly, the country has produced its own blockbuster, District 9, offering a resolutely de-centred outlook: for a change, the aliens do not conform with American hegemony and land in New York, Los Angeles or Washington... but in Johannesburg instead. Eventually, new social forms are appearing, creating dialectical relations between the different elements of change. Emerging countries appear as the greatest producers of such social and cultural forms.

\section{Four main themes}

14 This issue will present some analyses of societies in emerging countries, examined through their spatial dimensions, in order to generate new geographical approaches of those countries and to advance knowledge on emerging countries. To capture such multidimensional change, many different themes were possible: the affirmation of civil societies and democratisation process, in particular through new forms of social activism; the reorganisation of gender social relations; the development of leisure, tourism and more broadly consumer societies; the evolution and reconfiguration of the cultural sector, seen as an offering of cultural practices, and its growing worldwide dissemination (cinema for instance); urban planning policies and the local appropriation of global models ("mega-projects", heritage, etc.); the organisation of mega-events (Beijing Olympics in 2008, soccer World Cup in South Africa in 2010, etc.); complex migratory circulation, combining migration and movements of individuals with low to high levels of qualifications, etc. Not all of those themes were investigated by the authors who were selected for this issue: unfortunately, some of the themes are missing and some emerging countries are not represented, in particular in Latin America. The authors empirically explore four themes to investigate the way emergence translates itself spatially in everyday social geographies.

Emergence is first of all the result of strategies pursued by a number of stakeholders, in particular on a national and local scale. Leo Kloeckner and Thomas Radovcic sought to identify some of those players, respectively for China and South Africa, and 
investigated the way their actions, via the local appropriation of global models, have shaped urban space. City centres appear as strategic locations for the leaders of emergence. The promotion of "spiritual civilisation" in Shanghai and creative economy in Cape Town reflects the way international norms and narratives are used locally in order to transform society and develop metropolitan economy, against a backdrop of heightened global competition between cities.

Emergence has brought about a change in lifestyles, in particular the development of access to leisure. Marie Gibert and Emmanuelle Peyvel on Vietnam, and Benjamin Taunay and Philippe Violey on China look into socio-spatial practices of leisure, highlighting how the emergence of a middle class forms an "entertainment turn" that borrows from old models while integrating new ones. Those practices also reflect changes that occurred in the construction of territories and identities. However, the development of new social practices always brings new inequalities. Starting from a study of the food business in Hanoï, Gwenn Pulliat observes a growing bi-polarisation between a group whose consumption practices illustrate the emergence of Vietnam's capital, and a group of "socially excluded" classes who do not take part in this evolution.

The growth of metropolises and migration raises the question of transports, as well as bringing us to rethink gender issues. At the meeting point between those two themes, Claire Hancock (Mexico and Seoul) and Solène Baffi (Cape Town) show how women's mobility raises specific questions in the context of emerging cities, from public policies to everyday tactics. Once again, those studies reveal inequalities in access to the city, affecting more acutely the groups that suffer a treble discrimination because of their gender, social origin and race (in the case of South Africa) - those inequalities are however attenuated by the women's "ways of operating" in their everyday use of transport.

Other issues reveal the multi-dimensionality of emergence. The last two articles give an overview of environmental issues, for instance in connection with the development of production and urban sprawl (Yves Duchère on the Hanoi province), and major political changes that are often a corollary of emergence (Delphine Pagès-El Karoui on Egypt).

Finally, the "image" section will take us on a journey in the streets and square of Seoul, Mexico, Istanbul, Cape Town and Bangalore, to analyse spatial changes in the public spaces of emerging countries' big cities. These cities are affected by specific tensions: hybridization of urban models, relatively recent arrival of new populations from rural areas, social and economic inequalities, cultural and racial gaps, diversity of aspirations to democracy... Those various issues all contribute to shaping public urban spaces, in their form and in their practices.

\section{NOTES}

1. This issue of Echogéo is partly the outcome of the ACI Jeunes chercheurs « Une géographie des espaces publics dans les pays intermédiaires » («A geography of public spaces in intermediary 
countries »), $\mathrm{n}^{\circ} \mathrm{J}(6029$, which was attended, in addition to the authors of this introduction, by Valérie Gelézeau, Claire Hancock, Bruno Sabatier, Thierry Sanjuan and Annika Teppo. We are indebted to them for a lot of the materials presented here. We would like to thank everyone who attended the ACI, whether or not they were able to contribute to this issue. Myriam HoussayHolzschuch was supported by the ANR PERISUD ( ${ }^{\circ}$ Suds-07-046), under the supervision of JeanLouis Chaléard.

2. Less advanced countries being, by contrast, defined by a series of quantitative economic criteria.

3. In 2008, the Boston Consulting Group names out 14 « rapid growth economies ", including the BRIC countries as well as Argentina, Chile, Egypt, Hungary, Indonesia, Malaysia, Mexico, Poland, Thailand and Turkey. On the same year, PricewaterhouseCoopers mentions 20 emerging markets, adding Bangladesh, Iran, Nigeria, Pakistan, the Philippines, Saudi Arabia, South Africa and Vietnam to the Boston Consulting Group's list, to the exclusion of Chile and Hungary.

4. The Guardian, $1^{\text {st }}$ february 2011, http://www.guardian.co.uk/global-development/povertymatters/2011/feb/01/emerging-economies-turkey-jim-oneill

5. The Washington consensus is a body of standard measures that were imposed by international financial institutions (World Bank and International Monetary Fund) to countries with economic difficulties, with the support of the US Treasury.

6. J. Sgard's classification brings us back to the issue of the boundaries of emergence, since Russia, which is a member of the BRICS countries, is not part of it.

7. Some economists do however stress the necessity of looking into national and local strategies (Gabas, 2008 ; Piveteau et Rougier, 2010 ; Ruet, 2008).

INDEX

Thèmes : Sur le Champ - Sur le Terrain

\section{AUTEURS}

\section{ANTOINE FLEURY}

Antoine Fleury, afleury@parisgeo.cnrs.fr , is a researcher at the Centre National de Recherche Scientifique (CNRS), UMR 8504 “Géographie-cités" (CNRS, Paris 1 Panthéon-Sorbonne and Paris Diderot Universities).

\section{MYRIAM HOUSSAY-HOLZSCHUCH}

Myriam Houssay-Holzschuch, Myriam.Houssay@normalesup.org, is a geography lecturer at the University Joseph Fourier Grenoble 1,PACTE UMR 5194 (CNRS, IEPG, UJF, UPMF) and Institut Universitaire de France. 